\title{
PELATIHAN FOTOGRAFI DASAR BAGI PELAKU USAHA KECIL DAN MENENGAH (UKM) KECAMATAN LENGKONG KOTA BANDUNG
}

\author{
Yudhy S. Purwanto \\ waystopurwa@yahoo.co.id \\ Mira Veranita \\ mirave2198@gmail.com
}

\section{POLITEKNIK PIKSI GANESHA}

\begin{abstract}
ABSTRAK
Usaha Kecil Menengah (UKM) adalah salah satu faktor pembangunan ekonomi di Indonesia. Fakta bahwa perkembangan internet telah mencapai kebutuhan manusia yang sangat mendasar membuat UKM dapat memperluas bisnis mereka di seluruh dunia. Mereka, tentu saja, diharuskan untuk memahami beberapa keterampilan dasar dan keterampilan dasar untuk bertahan hidup di bisnis internet, seperti pangsa pasar elektronik, etika e-market, dan iklan emarket. Subjek inti dari iklan e-market adalah fotografi produk dan desain produk. Karena smartphone telah berkembang sangat maju saat ini, semua proses di atas dapat dilakukan melaluinya. Pelatihan ini dirancang khusus untuk tujuan itu, yaitu untuk mengembangkan keterampilan masyarakat UKM dalam fotografi produk ponsel cerdas dan cara mengemas produk mereka sehingga mereka dapat bersaing dan memenangkan persaingan di pasar elektronik. Pelatihan ini cukup berhasil yang ditunjukkan oleh antusiasme para peserta pelatihan dan menghasilkan beberapa fotografi produk yang sangat bagus. Hasil dari pelatihan ini adalah semakin banyaknya praktisi SME yang online dan mempromosikan produk mereka di internet.
\end{abstract}

Kata kunci: E-Market, Iklan, Fotografi Produk Smartphone, Desain.

\section{PENDAHULUAN}

Salah satu motor penggerak pertumbuhan ekonomi di Indonesia adalah pembangunan dan pertumbuhan Usaha Kecil dan Menengah (UKM).

Di Indonesia, pembangunan UKM merupakan upaya dalam menanggulangi pengangguran, memerangi kemiskinan juga upaya untuk pemerataan pendapatan.

Bila dilihat dari jumlah unit usahanya yang cukup banyak dan beragam di berbagai sektor ekonomi dan kontribusinya terhadap penciptaan kesempatan kerja, UKM menjadi salah satu motor penggerak bagi pembangunan ekonomi dan komunitas lokal. UKM sangat diharapkan menjadi salah satu pemain penting dalam penciptaan pasar baru di dalam maupun luar negeri.

Berdasarkan data yang dikeluarkan oleh departemen Koperasi, jumlah UMKM dari tahun 2008-2012 terus mengalami peningkatan sedangkan jumlah usaha besar cenderung berfluktuatif. 
Pada tahun 2011 usaha besar mengalami peningkatan sebesar 3.728 sementara jumlah UMKM dari tahun 2008 sampai tahun 2012 mengalami peningkatan sebesar $91,5 \%$ sedangkan usaha besar dari tahun 2008 sampai tahun 2012 mengalami peningkatan sebesar $17,80 \%$. Hal ini menandakan bahwa dalam pembangunan ekonomi di Indonesia UMKM selalu digambarkan sebagai sektor yang mempunyai peranan yang penting, karena sebagian besar jumlah penduduknya berpendidikan rendah dan hidup dalam kegiatan usaha kecil baik disektor tradisional maupun modern.

Pertumbuhan jumlah UKM di Indonesia yang semakin hari kian melonjak pesat, mau tidak mau mendorong para pelakunya untuk lebih kreatif dan inovatif dalam menyusun strategi pemasaran.. Seperti kita ketahui bersama, strategi pemasaran sering kali diibaratkan sebagai jantung kehidupan sebuah usaha. Karenanya saat ini para pelaku UKM harus bisa jeli dan teliti dalam menciptakan strategi pemasaran yang tahan banting di tengah ketatnya persaingan pasar.

Pelaku UKM harus semakin kreatif, dan bisa menentukan komoditas apa saja yang memiliki nilai jual cukup tinggi di pasaran, sehingga para pelaku UKM memiliki aturan analisis dalam dunia pemasaran modern yang kelak bisa digunakan untuk melacak dan mengukur seberapa potensial pasar yang dibidik.

Salah satu hambatan yang ditemui oleh para Pelaku UKM di Kecamatan Lengkong Kota Bandung adalah masalah Manajemen Pemasaran, terutama dalam memberikan pemahaman kepada para konsumen tentang produk, produksi dan mengenai bisnis UKM.

Dengan pesatnya perkembangan teknologi informasi dan komunikasi dewasa ini, Pemasaran UKM harus mampu memanfaatkan pemasaran Berbasis Online, baik itu melalui Pembukaan Toko Online, Apikasi Penjualan On Line maupun promosi dan pemasaran produk UKM dengan memanfaatkan Jejaring Sosial, sehingga bisa menjadi media yang bisa mewakili produk yang dibutuhkan oleh konsumen.

Untuk meningkatkan kemampuan Pelaku UKM dalam dokumentasi foto produk, serta meningkatkan kemampuan dalam editing foto produk yang nantinya akan digunakan dalam Pemasaran Online, sehingga diharapkan UKM dapat mempublikasikan foto produknya dengan dokumentasi yang bagus, memiliki nilai publikasi yang tinggi.

Selain itu, pelatihan ini juga dapat menjadi ajang pertemuan para pelaku UMKM di wilayah Kecamatan Lengkong, Kota Bandung, sehingga dapat mempererat tali sliaturahmi dan memperluas jaringan.

Khalayak sasaran pelatihan ini adalah 25 (duapuluh lima) orang pelaku UKM Kecamatan lengkong Kota Bandung, dengan klasifikasi:

\begin{tabular}{|c|l|c|c|}
\hline JM & KELURAHA & \multicolumn{2}{|c|}{ JENIS USAHA } \\
\hline $\mathbf{L}$ & \multicolumn{1}{|l|}{$\mathbf{N}$} & $\begin{array}{c}\text { Mak } \\
\text { anan }\end{array}$ & $\begin{array}{c}\text { Non } \\
\text { Makanan }\end{array}$ \\
\hline $\mathbf{5}$ & Cikawao & 3 & 2 \\
\hline $\mathbf{5}$ & Malabar & 4 & 1 \\
\hline $\mathbf{4}$ & Cijagra & 3 & 1 \\
\hline $\mathbf{4}$ & Burangrang & 3 & 1 \\
\hline $\mathbf{3}$ & Paledang & 2 & 1 \\
\hline $\mathbf{2}$ & Turangga & 1 & 1 \\
\hline $\mathbf{2}$ & Lingkar Selatan & 2 & 0 \\
\hline $\mathbf{2 5}$ & & & \\
\hline & & & \\
\hline
\end{tabular}

\section{METODE KEGIATAN}

Metode Kegiatan yang digunakan pada pelatihan ini adalah sebagai berikut:

a. Ceramah dan demonstrasi

Metode ini digunakan untuk memberikan informasi dan pemahaman peserta 
tentang hal-hal yang berkaitan dengan fotografi dan editing produk dasar, untuk kebutuhan Pemasaran pada Media On Line.

b. Praktik dan Pembimbingan

Metode ini digunakan untuk memberikan kesempatan berlatih membuat foto produk dengan menggunakan media digital camera dan handphone camera.

\section{HASIL DAN LUARAN}

Kegiatan pelatihan pada Program Pengabdian Pada Masyarakat ini dilaksanakan selama 2 (dua) hari yaitu:

Hari / tanggal: Rabu dan Kamis, tanggal 19 dan 20 April 2017

Tempat: Ruang Serbaguna Kantor Kecamatan Lengkong Kota Bandung.

Adapun pelaksanaan kegiatan

Pengabdian pada Masyarakat secara rinci adalah sebagai berikut:

1. Melakukan analisis Lapangan dan

Kebutuhan

Kegiatan Analisis lapangan dan analisis kebutuhan ini dikerjakan oleh Tim LPPM Politeknik Piksi Ganesha Bandung dan Kepala Bidang Ekonomi\&Pembangunan di Kantor Kecamatan Lengkong Bandung.

Berdasarkan orientasi lapangan, diperoleh gambaran bahwa hambatan yang dihadapi oleh para pelaku Usaha Kecil dan Menengah Kecamatan Lengkong dalam memasarkan produknya melalui media on line adalah karena belum tersedianya foto-foto yang menarikdan memancing keingintahuan konsumen mengenai produk yang dipasarkan.

Berdasarkan orientasi lapangan diperoleh gambaran bahwahal ini terjdi karena keterbatasan pengetahuan dan keterampilan dalam membuat foto produk dengan menggunakan camera digital maupun camera handphone, dan belum adanya upaya-upaya mengoptimalkan sumber-sumber informasi yang ada.
Selain itu kesulitan lainnya adalah pada ketersediaan alat untuk melakukan foto, misalnya studio mini, alas foto, lighting dan kamera.

2. Kerangka Pemecahan Masalah Berdasarkan uraian di atas, maka pemecahan masalah yang dilakukan secara operasional adalah sebagai berikut:

a. Diskusi secara intensif tentang:

- Karakteristik setiap kamera dan lensa yang akan digunakan, dan mana yang akan lebih ditekankan penggunaannya bagi para pelaku UKM.

- Memilih tema, lokasi dan waktu pengambilan gambar, pada saat pelatihan.

- Menentukan objek foto yang diinginkan serta karakteristiknya.

- Memilih dan menyiapkan peralatan yang dibutuhkan

b. Pemberian materi pelatihan tentang:

- Pengetahuan tentang Fotografi

- Pengetahuan Dasar Fotografi Produk

- Pembuatan lightbox

- Praktek memotret dengan produk UKM HP (Smartphone Photography)

\section{Fotografi}

Fotografi adalah seni mengambil gambar suatu objek dengan menggunakan alat yang disebut kamera. Pada dasarnya yang diambil dari suatu objek gambar bukanlah objek itu sendiri, melainkan pantulan cahaya yang dihasilkan oleh objek tersebut. Kamera merekam seberapa banyak cahaya yang dipantulkan oleh objek gambar sehingga dapat menghasilkan gambar yang sesuai dengan keinginan.

Untuk menghasilkan sebuah hasil karya yang bagus atau menarik ada beberapa faktor yang saling mendukung, yaitu:

a. Faktor yang paling utama adalah faktor pencahayaan, tanpa cahaya atau pencahayaan yang baik akan terlalu sulit untuk menghasilkan hasil karya yang bagus. 
b. Faktor kedua adalah fotografer. Fotografer yang memiliki kemampuan yang baik akan menentukan kualitas foto yang bagus atau menarik. Beberapa hal yang perlu dikuasai dan dimengerti oleh seorang fotografer antara lain adalah:

1) Posture, yaitu posisi tubuh saat mengambil foto. hal yang tidak diinginkan dalam proses mengambil gambar adalah munculnya gerakan/getaran yang dihasilkan oleh posisi tubuh dan nafas yang tidak sempurna.

2) Composition, adalah cara penempatan objek foto sehingga dapat menghasilkan sebuah karya yang dapat 'bercerita' dan dapat dinikmati oleh semua orang.

c. Faktor yang ketiga adalah kamera, tanpa kamera proses fotografi pun tidak terjadi. Kamera adalah alat pokok pada kegiatan fotografi. Faktor yang terakhir adalah faktor pendukung seperti lensa cadangan, alat bantu cahaya (lampu flash kamera), reflektor, tripod, dan lain-lainnya.

\section{Fotografi Produk}

Fotografi Produk adalah bidang fotografi yang dikhususkan pada pengembangan teknik-teknik mengambil gambar produk, baik dalam skala kecil maupun besar, terutama produk yang nampak (tangible). Kretova (2013:1) mengatakan bahwa, "Product photography is a genre in commercial photography aimed to demonstrate products to business customers or to showcase items produced by an organization or a single person. Product photographs are used in online shops and portfolios as well as in printed and digital catalogs."

Tujuan dari fotografi jenis ini jelas, yaitu mengambil gambar sebuah produk yang akan dijual. Karena tujuan tersebut, hasil foto juga dituntut untuk dapat lebih jelas dan dapat memberikan gambaran yang lengkap dan sesuai dengan misi yang diemban oleh produk tersebut. Berbagai jenis produk, terutama yang tangible dapat menggunakan jenis fotografi ini, diantaranya adalah: produk elektronik, fashion, asesoris, makanan, sampai produkproduk besar seperti mesin dan kendaraan.

Karena tujuannya yang berbeda, pada umumnya kebutuhan penunjang jenis fotografi ini juga terbilang berbeda dan membutuhkan kreativitas fotografernya. Fotografi produk sebaiknya menggunakan cahaya buatan (artificial) dan berbagai asesoris studio fotografi seperti: light meter, strobe, softbox, tripod, flash, additional flash, reflector, dll.

Perkembangan teknologi digital yang makin melesat membuat hampir semua kehidupan dan kebutuhan manusia berpusat pada hasil dan luaran teknologi, salah satunya adalah smartphone. Smartphone yang terintegrasi dengan internet memungkinkan manusia untuk dapat merangkum hampir seluruh kebutuhan hidupnya, mulai dari informasi, kehidupan sosial, aktualisasi diri, sampai pada tindakan jual-beli.

\section{Smartphone photography}

Saat ini, teknologi kamera digital yang ada pada smartphone dapat dikatakan sudah sangat maju. Walaupun tidak dapat disejajarkan dengan kamera digital SLR, tetapi fitur-fitur yang melengkapinya memberikan banyak alternatif untuk mengakomodasi daya kreativitas penggunanya. Jenis kamera digital disandarkan pada satuan piksel (pixel) yang menurut Präkel (2010:192), adalah, "the result of digital sampling and records the numerical data for the colour found at that location in the image. Pixels are not units and are not comparable from digital camera system to system as they have different sizes and, sometimes, different shapes. One million pixels are a megapixel (Mpx)."

Keuntungan yang dimiliki oleh smartphone, apabila dibandingkan dengan kamera DSLR adalah bahwa benda ini memangkas beberapa langkah untuk dapat dipublikasikan. Pengguna smartphone tidak lagi harus terhubung dengan komputer (baik PC maupun laptop) untuk dapat memuatnya di internet sehingga foto yang diambil dapat 
dengan serta merta di upload ke dunia maya. Keuntungan yang paling jelas adalah bahwa orang dapat langsung terkoneksi tanpa harus memikirkan jarak lagi. Keish (2015:7) menulis bahwa smartphone photography, "Eliminating the need to connect your camera to a computer for downloading makes you want to shoot more pictures. Shooting photographs becomes less hassle and more fun."

Selain foto diri (selfie) dan keadaan sekitar, kamera pada smartphone juga dapat digunakan dalam bidang penjualan produk. Menjamurnya Usaha Mikro, Kecil, dan Menengah (UMKM) yang didukung oleh tersedianya virtual store (toko dunia maya) membuat pergerakan bisnis dan pengenalan produk menjadi hal yang vital. Smartphone dapat mengakomodasi semua proses jual beli yang terjadi di dunia virtual tersebut; dari mulai pengambilan foto, editing foto, editing tulisan, sampai pada uploading dan transaksi. Semua proses terjadi dalam genggaman tangan tanpa harus melibatkan PC ataupun laptop.

Dalam kaitannya dengan fotografi produk, fotografi smartphone memerlukan beberapa kebutuhan tambahan seperti: cahaya (natural dan artificial), tripod (regular, tematik, atau gorilla tripod), monopod (selfie stick), dan juga lightbox. Lightbox adalah salah satu asesoris yang cukup penting dalam hal ini karena benda ini dapat memudahkan pengguna untuk dapat memanipulasi cahaya dan bayangan, menajamkan fokus, mengambil foto dari beberapa sudut, dan memberikan ruang bagi kreativitas pengguna.

\section{Pembuatan lightbox}

Lightbox adalah kotak dengan bentuk tertentu yang dapat mempermudah kita untuk melakukan pemotretan benda-benda tertentu. Alat ini biasanya gunakan untuk pemotretan produk penjualan, baik untuk tujuan komersial yang konvensional maupun online. Dengan lightbox hasil foto keliatan lebih terfokus dan indah. Fungsi alat ini adalah memantulkan cahaya kepada obyek foto, sehingga hasil foto akan terlihat lebih menonjol dan menarik.

Di pasaran banyak sekali beredar produk-produk lightbox atau softbox yang sudah sangat representatif untuk digunakan dalam proses pemotretan produk. Beberapa bahkan dapat dilipat dan sudah dilengkapi dengan lampu. Benda ini cukup mahal harganya, bergantung pada kualitas bahan dan kelengkapan asesoris yang mengikutinya.

Pada dasarnya, lightbox adalah sebuah kotak yang memiliki dinding-dinding transparan yang dapat meneruskan cahaya sehingga membarikan efek cahaya yang lembut dan dapat diatur intensitasnya. Oleh karena itu, lightbox pun dapat dibuat sendiri dengan biaya yang jauh lebih minim daripada harus membelinya di pasaran.

Bahan-bahan sederhana yang dibutuhkan dalam pembuatan lightbox antara lain adalah: kotak kardus yang cukup tebal, karton putih, karton hitam, kertas/plastik tipis, lem, selotip, dobeltip, gunting, dan cutter. Bahan tambahan setelah jadi adalah 2 atau 3 buah lampu duduk sebagai sumber cahaya.

\section{Permasalahan Peserta dan Solusinya}

Dari hasil tanya jawab dan praktek langsung pada saat program pelatihan, kami dapat melihat beberapa permasalahan yang menjadi penghambat perkembangan usaha para peserta, antara lain adalah:

a) Kemampuan penggunaan internet dan fitur-fiturnya yang masih sangat minim;

b) Kemampuan pemasaran yang masih konvensional dan apa adanya;

c) Ketidaktahuan akan penggunaan fitur kamera pada telepon genggam dan pemanfaatannya;

d) Ketidaktersediaan alat (e.g. telepon genggam, lampu, dan lightbox);

e) Rasa percaya diri yang kurang atas produk yang dihasilkan;

f) Tidak tersedianya komunitas yang dapat saling mendukung anggotanya. 
Dari beberapa permasalahan di atas, panitia pelaksana melakukan beberapa hal untuk mengatasinya, yaitu:

a) Memberikan pelatihan mengenai dasardasar penggunaan internet yang mudah dipahami;

b) Memberikan pelatihan tentang pemasaran, terutama yang berkaitan dengan pemasaran online;

c) Memberikan praktek penggunaan kamera telepon genggam dan pembuatan light box;

d) Memberikan pendampingan selama beberapa minggu setelah pelatihan; dan

e) Membuat komunitas dan memberikan masukan-masukan tentang pasar yang tepat bagi tiap-tiap produk.
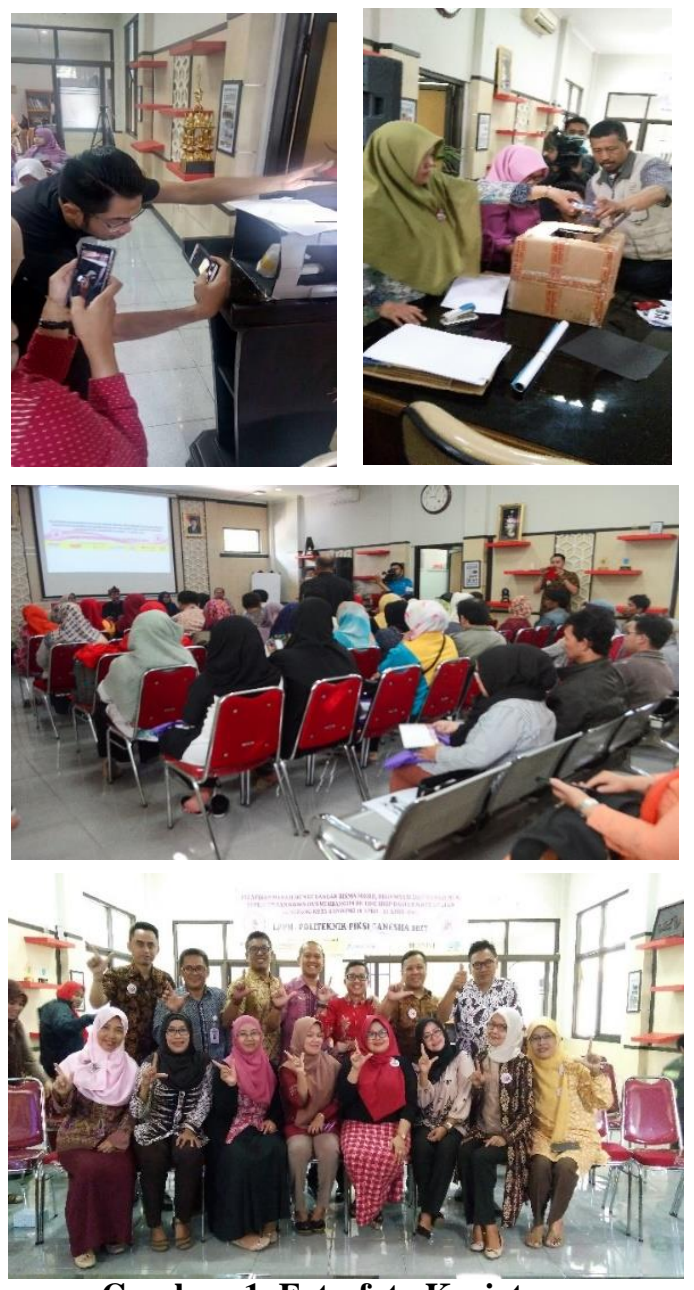

\section{KESIMPULAN}

Dari hasil pelatihan selama dua hari tersebut, dapat ditarik kesimpulan, yaitu:
1) Pelatihan mengenai e-marketing dan tips\&tricksnya harus sering dilakukan untuk membantu perkembangan UKM;

2) Masih terdapat beberapa aspek yang harus terus dibenahi dan ditingkatkan, terutama pada bagian internet marketing; dan

3) Pelatihan fotografi produk dan pembuatan light box dirasa cukup berhasil dan tepat sasaran terlihat dari apresiasi seluruh jajaran kecamatan dan antusiasme peserta.

Selain itu, kami juga bermaksud untuk memberikan beberapa saran, yaitu:

1) Pembuatan komunitas dan kelompokkelompok kerja harus dilakukan sebagai salah satu cara monitoring dan pengembangan UKM;

2) Kecamatan dapat diminta untuk membuat semacam inkubator bisnis bagi para pelaku UKM di wilayahnya; dan

3) Apabila dimungkinkan, komunitas dapat bekerjasama dengan kecamatan setempat untuk membuat acara khusus (bazaar, pasar malam, dll.) sebagai ajang pengemalan produk UKM.

\section{DAFTAR PUSTAKA}

Galer, Mark. 2007. Photography Foundations for Art \& Design: The Creative Photography Handbook. Focal Press/Elsevier, Oxford, UK

Grey, Christopher. 2004. Master Lighting Guide for Portrait Photographers. Armherst Media Inc., Buffalo, NY, USA

https://digital-photography-school.com/

four-rules-of-photographic-compo sition/

https://id.wikipedia.org/wiki/Fotografi https://en.wikipedia.org/wiki/Photograp hy

http://id.wikihow.com/Membuat-LightBox-untuk-Pemotretan

Keish, Nick. 2015. Photographing Your Life with Your Smartphone (ebook). Nick Keish for FOREVER. www.howtophotographyourlife.com 
Kretova, Aleksandra. 2013. Product Photography for an Online Store and Printed Catalogue. Helsinki Metropolia University of Applied Sciences, Helsinki.

Präkel, David. 2010. The Visual Dictionary of Photography. AVA Publishing, Switzerland.

Simon, Dan. 2004. Digital Photography Bible, Desktop Edition. Wiley Publishing Inc. Indianapolis: Indiana, USA

Totman, Ben. 2015. Smartphone Photography Guide (ebook). www.photographytricks.com/wp.../. 